\title{
ELRC
}

Journal: Education and Language Research Center

Vol. 1 No. 1, 2021, /30-39

\section{APPLICATION OF CONTEXTUAL TEACHING AND LEARNING TO INCREASE AQIDAH AKHLAQ LEARNING OUTCOMES}

\author{
${ }^{1}$ Nurul Istiqomah ${ }^{2}$ Abdullah \\ Email: ${ }^{1}$ nurulistiqomah1@gmail.com Coauthor: ${ }^{2}$ abdullah_sakka@iaingorontalo.ac.id \\ ${ }^{1}$ Madrasah Ibtidaiyah Raden Rahmat, Surabaya, ${ }^{2}$ IAIN Sultan Amai Gorontalo, Indonesia
}

Article Info

Received:

28 September 2021

Accepted:

10 Oktober 2021

Published:

25 November 2021

Key Word

Kata Kunci:

\begin{abstract}
The purpose of this classroom action research is to enhance the result study of moral aqidah education with Contextual Teaching and Learning learning in 2nd grade students of MI Raden Rahmat. The form of this research is classroom action research consisting of two cycles, each cycle consists of four stages, namely planning, implementation, observation and reflection. As the research subject is a 2nd grade students of MI Raden Rahmat. In data collection, the method used as the main method is observation and test. Based on the results of research on the learning models application of Contextual Teaching and Learning to 2nd grade students of MI Raden Rahmat, with a total of 13 students have enhancement on the study result, which is before the action, only $30.81 \%$ of students studied thoroughly, and after the action became $100 \%$ of students studied thoroughly. Thus, it can be concluded that the learning model application of the Contextual Teaching and Learning is proven to be able to improve study result of moral aqidah education in 2nd grade students of MI Raden Rahmat

Learning Outcomes; Contextual Teaching and Learning.
\end{abstract}

\section{ABSTRAK}

Tujuan penelitian tindakan kelas ini adalah untuk meningkatkan hasil belajar pendidikan akidah akhlak dengan pembelajaran Contextual Teaching and Learning pada siswa kelas 2 MI Raden Rahmat. Bentuk penelitian ini adalah penelitian tindakan kelas terdiri dari dua siklus, tiap siklus terdiri dari empat tahapan yaitu perencanaan, pelaksanaan, observasi dan refleksi. Sebagai subjek penelitian adalah siswa kelas 2 MI Raden Rahmat. Dalam pengumpulan data, metode yang dipergunakan sebagai metode pokok adalah observasi dan tes. Berdasarkan hasil penelitian penerapan model pembelajaran Contextual Teaching and Learning pada siswa kelas 2 MI Raden Rahmat, dengan jumlah siswa sebanyak 13 anak mengalami peningkatan hasil belajar yaitu sebelum tindakan hanya 30,81\% siswa belajar tuntas, dan setelah tindakan menjadi $100 \%$ siswa belajar tuntas. Dengan demikian dapat disimpulkan bahwa dengan penerapan model pembelajaran Contextual Teaching and Learning terbukti dapat meningkatkan hasil belajar pendidikan akidah akhlak pada siswa Kelas 2 MI Raden Rahmat.

Peningkatkan hasil belajar; Pembelajaran Contextual Teaching and Learning. 


\section{PENDAHULUAN}

Pendekatan Contextual Teaching and Learning (CTL) merupakan konsep pembelajaran yang menarik untuk diterapkan, karena berfungsi membantu guru dalam mentransfer materi dengan cara mengaitkan antara materi yang diajarkan dengan situasi nyata siswa, sehingga pembelajaran saling terkait dengan kehidupan mereka sebagai anggota keluarga dan masyarakat. ${ }^{1} \mathrm{Hal}$ ini jika dikaitkan dengan peningkatan kemampuan siswa berfikir kritis pada mata pelajaran Aqidah Akhlak, maka penanaman konsep harus terkait dengan bahan ajar yang sesuai dengan kurikulum yang ditetapkan melalui KMA $183 .{ }^{2}$

Kemampuan berpikir kritis siswa memerlukan peningkatan dari guru. ${ }^{3}$ Selain itu, penting untuk secara maksimal mengintegrasikan pendidikan karakter ke dalam pembelajaran Aqidah Akhlak, melalui pendekatan konteks. ${ }^{4}$ Secara umum siswa akan terlatih dan memiliki keterampilan berpikir tingkat tinggi jika guru mampu memfasilitasinya melalui metode pembelajaran yang berpusat pada siswa, serta mampu menanamkan kebermaknaan dalam proses pembelajaran. Oleh sebab itu, perlu sebuah strategi pembelajaran yang mempu mewujudkan tercapainya tujuan pembelajaran. Penggunaan strategi pembelajaran kontekstual atau Contextual Teaching and Learning (CTL) menjadi solusi untuk mengaitkan antara materi ajar dan lingkungan nyata siswa. Hal ini disebabkan landasan filosofis CTL adalah konstruktivisme, ${ }^{5}$ yaitu filosofi belajar yang menekankan bahwa belajar tidak hanya sekedar menghafal, tetapi mengkonstruksikan atau membangun pengetahuan dan keterampilan baru lewat fakta- fakta atau preposisi yang mereka alami dalam kehidupannya, guna peningkatan kompetensi siswa ${ }^{6}$ yang memiliki keragaman latar belakang. Sedangkan inti dari pembelajaran CTL adalah inquiry (menemukan). Jadi, pembelajaran harus dikemas dalam format "siswa menemukan sendiri". ${ }^{7}$

Realita di lapangan menunjukkan bahwa Materi Aqidah Akhlak sering disampaikan secara ekspositori. sehingga posisi guru dianggap sebagai sumber belajar satu satunya. Hal ini menyebabkan pembelajaran kurang tertarik dan siswa kurang aktif dalam merespon materi pembelajaran. Hal ini menunjukkan bahwa interaksi dan komunikasi yang terkait dengan keterlibatan siswa pada proses pembelajaran masih kurang, sehingga materi Aiqdah Akhlak yang berisi konsep actuating Al-Qur'an dan Hadits, ${ }^{8}$ tentang adab bersin dan menguap tidak efektif jika diajarakan, terlihat dari nilai ketuntasan materi yang diperoleh siswa masih rendah.

${ }^{1}$ Tamam Syaifuddin, Luthfiyah Nurlaela, and Sukma Perdana P, "Contextual Teaching and Learning (CTL) Model to Students Improve Learning Outcome at Senior High School of Model Terpadu Bojonegoro," IJORER: International Journal of Recent Educational Research 2, no. 5 (2021): 528-35, https://doi.org/10.46245/ijorer.v2i5.143.

${ }^{2}$ Misbakhus Surur and Muhamad Khoirur Roziqin, "Islamic Education Learning Process in Evaluation Curriculum : The Minister of Religion Decree No . 183 and 184 of 2019” 1, no. 1 (2021): 2-6.

${ }^{3} \mathrm{~T} M$ Rizti and E Prihatnani, "Efektivitas Model Pembelajaran 3CM (Cool-Critical-CreativeMeaningfull) Terhadap Kemampuan Berpikir Kritis Siswa SMP,” Mosharafa: Jurnal ... 10 (2021): 213-24, https://journal.institutpendidikan.ac.id/index.php/mosharafa/article/view/945.

${ }^{4}$ Asti Inayah Ani Anriani Sobandi, "Pengaruh Efektifitas Pembelarana Daring Terhadap Prestasi Siswa Pada Mapel Aqidah Akhlaq," THORIQOTUNA: JURNAL PENDIDIKAN ISLAM 4, no. 2 (2021): 301-19, https://doi.org/https://doi.org/10.47971/tjpi.v4i2.359.

${ }^{5}$ Evi Susilowati, "Penggunaan 'Contexual Teaching and Learning' Dalam Pembelajaran Menulis Teks Puisi,” Dinamika 2, no. 1 (2019): 19, https://doi.org/10.35194/jd.v2i1.676.

${ }^{6}$ Ibnu Rawandhy N. Hula, "Peningkatan Kompetensi Kaidah Bahasa Arab Bagi Pemula Menggunakan Al-Tadribat Al-Lughawiyah,” Al-Ta'rib 8, no. 2 (2020): 213-28, https://doi.org/https://doi.org/10.23971/altarib.v8i2.2054.

${ }^{7}$ Fahmi, "Strategi Pembelajaran Contextual Teaching and Learning Untuk Meningkatkan Keterampilan Berpikir Tingkat Tinggi," Prosiding Seminar Nasional Pendidikan IPA 2016, no. September 2016 (2016): 121-28.

8 Ibnu Rawandy N. Hula Qomaria Abusama, Kasim Yahiji, Damhuri, “Actuating Pendidikan Dalam Pandangan Al- Qur'an Dan Hadits,” Jurnal Al-Himayah 3, no. 3 (2020): 298-310, https://journal.iaingorontalo.ac.id/index.php/ah/article/view/2125. 
Data riset tahun 2021 menunjukkan bahwa penelitian terkait dengan Contextual Teaching and Learning (CTL) dalam rangka meningkatkan hasil belajar sudah banyak dilakukan, hal ini dapat dilihat dari sejumlah data kepustakaan yang telah diteliti dan terpublikasi di berbagai jurnal. Diantaranya penelitian yang berjudul "Learning from the Past: Meta-Analysis of Contextual Teaching-Learning of the Past Decade. Hasil penelitian ini menyimpulkan bahwa: ukuran efek keseluruhan penelitian adalah 0,88 (efek besar). Hasil analisis moderator menunjukkan bahwa pelaksanaan CTL dimoderatori oleh variabel tingkat pendidikan dan sumber publikasi. Di sisi lain, heterogenitas studi mencerminkan bahwa masih ada variabel moderasi lain yang terkait dengan efektivitas CTL, namun dengan keterbatasan penelitian yang dibahas dapat dijadikan sebagai ide dasar untuk pelaksanaan penelitian selanjutnya. ${ }^{9}$ Penelitian lain berjudul:Prospek Pembelajaran Aqidah Akblakmenggunakanmodelcontextualteachingandlearningdi Sekolah Dasar, menyimpulkan bahwa model CTL dapat dijadikan sebagai pendekatan pada prosesinternalisasinilai-nilai Islamdalam pembelajaran Aqidah Akhlak. ${ }^{10}$

Demikian pula penilitian yang berjudul "Contextual Teaching and Learning approach in social science: its role to encourage pupils' cognitive learning achievement" yang menyimpulkan Peningkatan hasil belajar menunjukkan hasil penelitian dari siklus I ke siklus II; yaitu, nilai rata-rata hasil belajar siswa meningkat dari $26,47 \%$ menjadi $88,23 \% .{ }^{11}$ Serta penelitian Sarawati, dkk, Development of Mobile Learning (My Repro) Based on Contextual Teaching Learning to Improve Cognitive Understanding Senior High School Student, menyimpulkan bahwa nilai validasi ahli materi dan ahli media masing-masing sebesar 92,39\% dan 92,61\% dengan kriteria sangat valid. Analisis pemahaman kognitif siswa menunjukkan kriteria tinggi dengan nilai rata-rata $\mathrm{N}$-gain sebesar 0,70 (kriteria tinggi). Berdasarkan hasil analisis penelitian, dapat disimpulkan bahwa media pembelajaran mobile learning berbasis pembelajaran kontekstual telah valid dan efektif digunakan sebagai sumber belajar siswa SMA. ${ }^{12}$

Dari sampel penelitian di atas, peneliti ingin menerapkan Contextual Teaching Learning lebih kepada peningkatan hasil belaajr siswa, yang lebih difokuskan kepada mata pelajaran Aqidah Akhlak, terutama pada materi Adab Bersin dan Menguap. Penelitian ini menjadi penting karena hasil pengamatan menunjukkan bahwa hasil belajar siswa kelas 2 MI Raden Rahmat masih rendah. Prosentase hasil pengamat menunjuukan bahwa ketuntasan siswa hanya $30,81 \%$ dari 13 siswa. Pada materi ini, siswa masih banyak yang belum memahami tentang adab bersin dan menguap yang sesuai dengan ajaran Nabi Muhammad SAW. Selain itu, siswa kurang suka mengamalkan adab-adab bersin, dimana mengamalkan adab-adab bersin dan menguap dianggap tidak penting dalam kehidupan sehari-hari. Serta kurangnya kesadaran dalam pentingnya belajar mata pelajaran akidah akhlak.

Dari hasil pengamatan dan penelitian di atas menunjukkan bahwa pembelajaran akidah akhlak perlu diperbaiki guna peningkatan kualitas hasil belajar, maka guru yang meneliti berusaha meningkatkan hasil belajar akidah khusunya materi adab bersin dan menguap pada siswa kelas 2 MI Raden Rahmat Prambon-Sidoarjo. Untuk mengatasi hal tersebut, maka dalam mempelajari suatu konsep/prinsip-prinsip akidah akhlak diperlukan pengalaman langsung

${ }^{9}$ Maximus Tamur et al., "Learning from the Past: Meta-Analysis of Contextual Teaching-Learning of the Past Decade," International Journal of Education \& Curriculum Application 4, no. 1 (2021): 1-10, https://doi.org/https://doi.org/10.31764/ijeca.v4i1.3981.

${ }^{10}$ Zunaidi M Rasid Harahap, "Prospek Pembelajaran Aqidah Akhlak Menggunakan Model Contextual Teaching Learning Di Sekolah Dasar," EDUSOSHUM: Journal of Islamic Education and Social Humanities 1, no. 1 (2021): 45-54, https://doi.org/10.52366/edusoshum.v1i1.8.

11 Rikardus Ruto et al., "Contextual Teaching and Learning Approach in Social Science: Its Role to Encourage Pupils' Cognitive Learning Achievement,” Journal of Research in Instructional 1, no. 1 (2021): 43-52, https://doi.org/10.30862/jri.v1i1.11.

12 Shinta Almayra Saraswati et al., "Journal of Innovative Science Education Development of Mobile Learning ( My Repro ) Based on Contextual Teaching Learning to Improve Cognitive Understanding Senior High School Student," Journal of Innovation Science Education, no. 37 (2021): 37-48, https://doi.org/10.15294/JISE.V10I1.47824. 
melalui pendekatan pembelajaran yang membawa siswa untuk mengaplikasikan antara pengetahuan yang dimilikinya dengan penerapannya dalam kehidupan sehari-hari. Idealnya perlu inovasi baru dalam pembelajaran.

Proses pembelajaran yang diharapkan dapat meningkatkan hasil belajar siswa lebih tinggi dari sebelumnya. Dalam hal ini peneliti akan menggunakan cara yang berbeda, yaitu dengan menggunakan pendekatan Contextual Teaching and Learning (CTL). Sehingga penelitian ini tidak saja berupaya meningkatkan prestasi belajar, namun berorietasi pada upaya mengetahui apakah model CTL dapat meningkatkan hasil belajar khusus pada materi adab bersin dan menguap bagi siswa kelas 2 di MI Raden Rahmat.

\section{METODE}

Penelitian ini merupakan jenis penelitian bersifat Penelitian Tindakan Kelas (PTK) atau Classroom Action Research yang dilakukan secara kolaboratif antara peneliti dan guru mata pelajaran. Adapun penelitian ini menggunakan model penelitian tindakan Kurt Lewin. Dalam model Kurt Lewin digambarkan bahwa ada 4 komponen pokok dalam setiap siklusnya, diantaranya: Perencanaan (Planning), Tindakan (Acting), Pengamatan (Observing) dan Refleksi (Reflekting). Penelitian ini dilaksanakan di kelas 2 Semester Ganjil Tahun 2021-2022, bertempat di Madrasah Ibtidaiyah Raden Rahmat. Subjek penelitian tindakan kelas ini yaitu siswa kelas 2 Madrasah Ibtidaiyah Raden Rahmat. Jumlah siswa yang menjadi subjek penelitian adalah sebanyak 13 siswa terdiri dari 5 siswa perempuan dan 8 siswa laki-laki.

Teknik pengumpulan data pada penelitian ini adalah sebagai berikut: observasi, dan test. Setelah melakukan proses pengumpulan data, selanjutnya menganalisis data tersebut. Analisis dari data yang diperoleh berupa: penilaian observasi guru dan siswa, penilaian tes, penilaian ketuntasan belajar.

\section{HASIL PEMBAHASAN}

Hasil penelitian dimulai dengan kondisi awal dengan pemberian tes awal untuk mengetahui kondisi awal prestasi belajar siswa.

Tabel 1.1

Frekuensi dan Grafik Nilai Hasil Belajar

\begin{tabular}{cccc}
$\begin{array}{c}\text { N } \\
0\end{array}$ & Nilai & Frekuensi & Prosentase \\
\hline 1 & $21-30$ & 1 & $7,69 \%$ \\
\hline 2 & $31-40$ & 3 & $23,07 \%$ \\
\hline 3 & $41-50$ & 2 & $15,38 \%$ \\
\hline 4 & $51-60$ & 2 & $15,38 \%$ \\
\hline 5 & $61-70$ & 1 & $7,69 \%$ \\
\hline 6 & $71-80$ & 2 & $15,38 \%$ \\
\hline 7 & $81-90$ & 1 & $7,69 \%$ \\
\hline 8 & $91-100$ & 1 & $7,69 \%$ \\
\hline \multicolumn{2}{c}{ Jumlah } & 13 & $100 \%$ \\
\hline
\end{tabular}

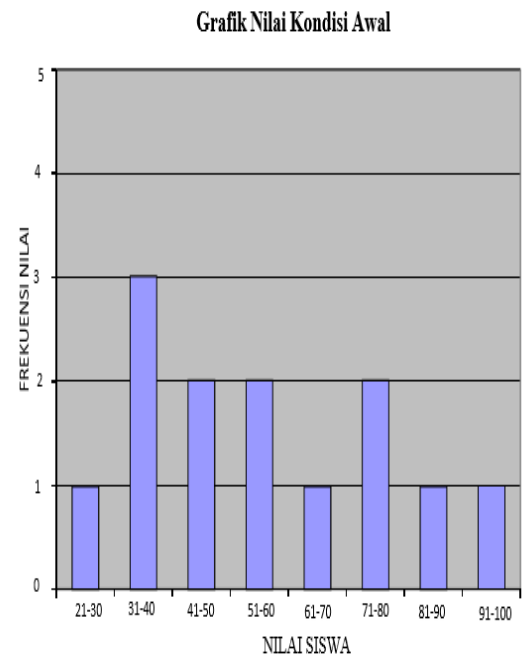

Dari tabel di atas dapat dilihat bahwa nilai terendah yang diperoleh siswa adalah 25,nilai tertinggi adalah 95, dan rata-rata nilainya 57,32 serta siswa yang telah belajar tuntas baru $30,81 \%$, dari pihak sekolah ketuntasan siswa diharapkan mencapai lebih dari 75\%, maka masih banyak siswa yang belum mencapai nilai ketuntasan $(\mathrm{KKM}=75)$, sehingga perlu 
diadakan tindakan.

Setelah melaksanakan tindakan pada setiap siklus diperoleh hasil peningkatan hasil belajar akidah akhlak pada materi adab bersin dengan menggunakan model pembelajaran Contextual Teaching and Learning. Pada siklus I disampaikan kompetensi dasar mengidentifikasi menerapkan adab bersin dan menguap dengan indikator menyebutkan adab-adab bersin dan menguap. berikut:

Selanjtunya diuraikan dalam tahapan yang berupa siklus-siklus pembelajaran sebagai

\section{Siklus I}

Analisis hasil penelitian berdasarkan pelaksanaan tindakan, observasi dari sikap dan perilaku siswa pada siklus I dapat dikemukakan sebagai berikut:

a. Siswa senang dengan mata pelajaran yang diajarkan, sehingga tertarik dengan materi pelajaran.

c. Siswa cukup aktif mendengarkan penjelasan guru saat KBM.

d. Tertarik dengan media yang digunakan.

e. Sebagian siswa belum dapat menerima pelajaran yang diajarkan.

f. Siswa cukup aktif menjawab pertanyaan guru, meskipun masih malu dan masih takut berpendapat.

g. Semangat dalam KBM lumayan baik.

h. Keaktifan siswa dalam mengerjakan tugas masih perlu ditingkatkan.

i. Siswa belum dapat memecahkan masalah yang berkaitan dengan tugas dari guru dengan baik.

j. Siswa belum dapat mengerjakan soal tes dengan baik. ${ }^{13}$

Tabel 1.2. Frekuensi dan Grafik Nilai Prestasi Belajar Siswa Siklus 1 Sebelum Dan Sesudah Tindakan

\begin{tabular}{ccc|c} 
No. & Nilai & $\begin{array}{c}\text { Sebelum } \\
\text { Tindakan }\end{array}$ & $\begin{array}{c}\text { Sesudah } \\
\text { Tindakan }\end{array}$ \\
\hline 1 & $21-30$ & $7,69 \%$ & $0 \%$ \\
\hline 2 & $31-40$ & $23,07 \%$ & $7,69 \%$ \\
\hline 3 & $41-50$ & $15,38 \%$ & $7,69 \%$ \\
\hline 4 & $51-60$ & $15,38 \%$ & $7,69 \%$ \\
\hline 5 & $61-70$ & $7,69 \%$ & $15,38 \%$ \\
\hline 6 & $71-80$ & $15,38 \%$ & $7,69 \%$ \\
\hline 7 & $81-90$ & $7,69 \%$ & $23,07 \%$ \\
\hline 8 & $91-100$ & $7,69 \%$ & $30,77 \%$ \\
\hline
\end{tabular}

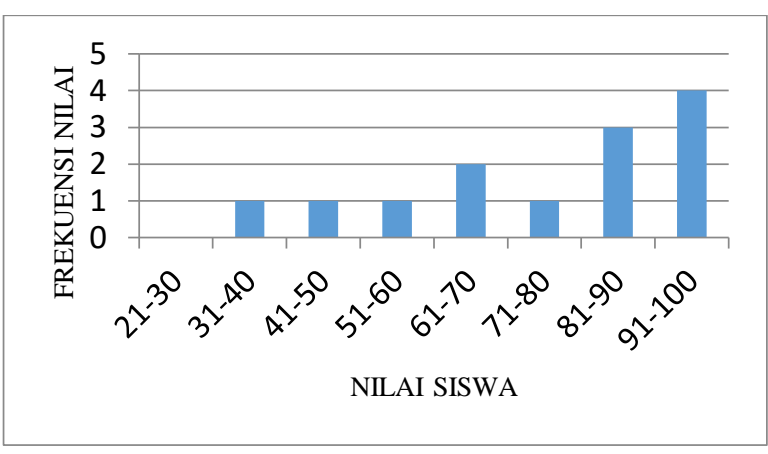

Gambar 2. Grafik Nilai Siklus I

Dari hasil analisa data perkembangan hasil belajar siswa siklus I dapat disimpulkan bahwa persentasi hasil tes siswa yang tuntas naik 61,54\% dengan nilai batas tuntas 75 ke atas, siswa yang tuntas belajar di siklus I sebesar $61,54 \%$, yang semula pada tes awal hanya terdapat $30,81 \%$ siswa mencapai batas tuntas. Besarnya nilai terendah yang diperoleh siswa pada saat tes awal sebesar 25 dan pada siklus I sebesar 35. Untuk nilai tertinggi terdapat kenaikan dari 95 naik menjadi 100 dan nilai rata-rata kelas yang pada tes awal sebesar 57,32 naik pada tes siklus I menjadi 76,51.

\footnotetext{
${ }^{13}$ Arif Mustaqim and Ibnu Rawandhy N Hula, "Increasing Learning Outcomes Through," Journal:Education and Language Research Center(ELRC) 1, no. 1 (2021): 1-10, https://doi.org/https://doi.org/10.31219/osf.io/vgebx.
} 


\section{Siklus II}

Peneliti melaksanakan tindakan pada siklus II dengan materi adab bersin dan menguap. Pembelajaran menggunakan media nyata, melakukan pembelajaran yang lebih kompleks. Analisis hasil penelitian berdasarkan pelaksanaan tindakan, observasi dari sikap dan perilaku siswa pada siklus II dapat dikemukakan sebagai berikut:

a. Siswa senang dengan mata pelajaran yang diajarkan.

b. Siswa tertarik dengan materi pelajaran.

c. Siswa aktif mendengarkan penjelasan guru saat KBM.

d. Tertarik dan senang dengan media yang digunakan.

e. Siswa dapat menerima pelajaran yang diajarkan dengan baik.

f. Siswa aktif menjawab pertanyaan guru dan mau berebut menjawab pertanyaan guru.

g. Siswa sangat semangat dalam KBM.

h. Siswa aktif dalam mengerjakan tugas dari guru.

i. Siswa sudah dapat memecahkan masalah yang berkaitan dengan tugas dari guru dengan baik.

j. Siswa dapat mengerjakan soal tes dengan baik.

\section{Tabel 1.3. Frekuensi dan Grafik Nilai Prestasi Belajar Siswa Siklus II Sebelum Dan Sesudah Tindakan}

\begin{tabular}{cccc} 
No. & Nilai & $\begin{array}{c}\text { Sebelum } \\
\text { Tindakan } \\
(\text { Siklus I) }\end{array}$ & $\begin{array}{c}\text { Sesudah } \\
\text { Tindakan } \\
\text { (Siklus II) }\end{array}$ \\
\hline 1 & $21-30$ & $0 \%$ & $0 \%$ \\
\hline 2 & $31-40$ & $7,69 \%$ & $0 \%$ \\
\hline 3 & $41-50$ & $7,69 \%$ & $0 \%$ \\
\hline 4 & $51-60$ & $7,69 \%$ & $0 \%$ \\
\hline 5 & $61-70$ & $15,38 \%$ & $0 \%$ \\
\hline 6 & $71-80$ & $7,69 \%$ & $30,77 \%$ \\
\hline 7 & $81-90$ & $23,07 \%$ & $30,77 \%$ \\
\hline 8 & $91-100$ & $30,77 \%$ & $38,46 \%$ \\
\hline
\end{tabular}

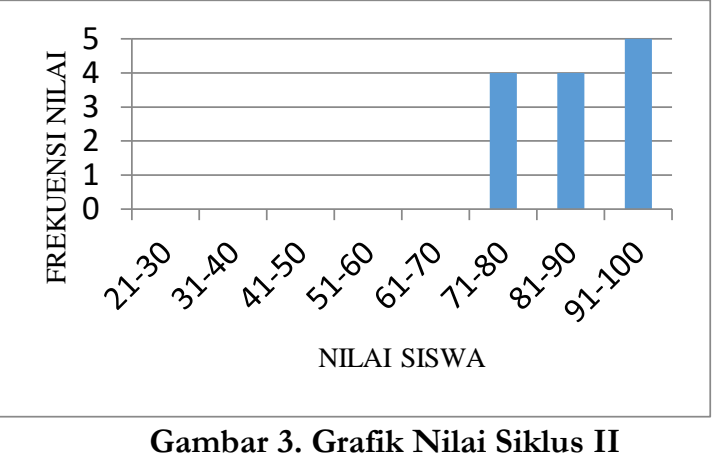

Gambar 3. Grafik Nilai Siklus II

Dari tabel dan grafik di atas dapat dilihat bahwa nilai terendah yang diperoleh siswa pada siklus I naik menjadi 35; dan pada siklus II naik lagi menjadi 80. Nilai tertinggi yang diperoleh siswa pada tes siklus I dan II 100. Nilai rata-rata kelas juga terjadi peningkatan yaitu pada tes siklus I 76,51 naik pada siklus II 81,92. Siswa belajar tuntas pada siklus I 61,54 \% pada siklus II naik menjadi 100\%.

Tabel 1.4. Hasil Tes Sebelum Tindakan, Siklus I, Siklus II

\begin{tabular}{cccc} 
Kriteria & Tes Awal & Siklus I & Siklus II \\
\hline Nilai terendah & 25 & 35 & 80 \\
\hline Nilai tertinggi & 95 & 100 & 100 \\
\hline Rata-rata nilai & 57,32 & 76,51 & 81,92 \\
\hline Siswa belajar tuntas & $\mathbf{3 0 , 8 1} \%$ & $\mathbf{6 1 , 5 4} \%$ & $\mathbf{1 0 0} \%$ \\
\hline
\end{tabular}


Hasil perbandingan mulai dari tes Awal, Siklus 1 dan II, diketahui bahwa:

1) Nilai terendah yang diperoleh siswa pada tes awal 25; pada siklus I naik menjadi 35; dan pada siklus II naik lagi menjadi 80.

2) Nilai tertinggi yang diperoleh siswa pada tes awal sebesar 95; pada siklus I naik menjadi 100; dan pada siklus II 100.

3) Nilai rata-rata kelas juga terjadi peningkatan yaitu pada tes awal sebesar 57,32, siklus I 76,51; dan pada siklus II 81,92.

4) Untuk siswa tuntas belajar (nilai ketuntasan 75) pada tes awal 30,81\%, tes siklus I $61,54 \%$ setelah dilakukan refleksi terdapat 5 siswa yang tidak tuntas (nilai ulangan dibawah 75), namun secara keseluruhan sudah meningkat hasil belajarnya bila dilihat dari presentase ketuntasan siswa, dan pada tes siklus II semua siswa sudah mencapai ketuntasan.

Dari analisis data dan diskusi terhadap pelaksanaan pembelajaran pada siklus II, secara umum telah menunjukkan perubahan yang signifikan. Guru dalam melaksanakan pembelajaran semakin mantap dan luwes dengan kekurangan-kekurangan kecil diantaranya kontrol waktu dan buku pelajaran yang masih kurang memadai bagi siswa.

Secara kognitif prestasi belajar siswa meningkat,selain itu hasil belajar afektif dan psikomotorik siswa juga meningkat. Hal ini terbukti adanya peningkatan siswa mencetuskan pendapat, mengeluarkan pendapat, berinteraksi dengan guru, mampu medemonstrasikan, kerjasama dengan kelompok meningkat, dan menyelesaikan soal-soal latihan. Dengan partisipasi siswa yang aktif dan kreatif siswa dalam pembelajaran yang semakin meningkat, suasana kelaspun menjadi lebih hidup dan menyenangkan dan pada akhirnya hasil belajar pendidikan akidah akhlak siswa kelas 2 MI Raden Rahmat meningkat. Berdasarkan peningkatan hasil belajar yang telah dicapai siswa maka pelaksanaan Penelitian Tindakan Kelas (PTK) dianggap cukup dan diakhiri pada siklus ini.

Berdasarkan hasil pelaksanaan pada siklus I dan II dapat dinyatakan bahwa pembelajaran pendidikan akidah akhlak siswa kelas 2 MI Raden Rahmat menggunakan model pembelajaran Contextual Teaching and Learning dapat meningkatkan hasil belajar siswa kelas 2 MI Raden Rahmat.

Pada siklus I setelah diadakan tes kemampuan awal dilanjutkan dengan siswa menerima materi pelajaran tentang adab bersin. Proses pembelajaran disampaikan dengan strategi dan terencana dimulai dari kegiatan awal, inti dan penutup. Kegiatan ini terfokus mengaktifkan siswa mulai dari memperhatikan penjelasan, melakukan pengamatan untuk memperoleh kesimpulan, tugas kelompok, berdiskusi yang diakhiri dengan tes. Setelah dilaksanakan siklus I dan dievaluasi dapat dilihat adanya peningkatan hasil belajar siswa yaitu masih ada 5 siswa memperoleh nilai kurang dari 75 atau siswa yang tuntas $61,54 \%$ dan nilai rata-rata siswa 76,51.

Siklus II merupakan lanjutan dari siklus sebelumnya untuk memantapkan dan mencapai tujuan penelitian. Pembelajaran yang disampaikan tentang perkembangbiakan makhluk hidup dengan menggunakan pendekatan kontekstual lebih optimal. Kegiatan belajar mengajar disampaikan dengan strategi terencana sebagaimana siklus I dan kegiatan pembelajaran dilaksanakan lebih optimal. Hasil siklus II menunjukkan peningkatan hasil belajar siswa yaitu nilai rata-rata siswa 81,92. Siswa belajar tuntas mencapai 100\%.

Berdasarkan data di atas dapat disimpulkan bahwa prestasi belajar siswa meningkat, baik secara kognitif, afektif maupun psikomotorik. Dengan demikian penggunaan model pembelajaran Contextual Learning and Teaching pembelajaran akidah akhlak materi adab bersin dan menguap dapat meningkatkan hasil belajar siswa kelas 2 MI Raden Rahmat. 


\section{PENUTUP}

Berdasarkan hasil penelitian dan pembasannya dapat disimpulkan bahwa melalui pembelajaran dengan model pembelajaran Contextual Teaching and Learning dapat meningkatkan hasil belajar pendidikan aqidah akhlak pada materi adab bersin dan menguap pada siswa kelas 2 MI Raden Rahmat. Hal ini dapat dilihat dari nilai rata-rata kelas terjadi peningkatan yaitu pada tes awal sebesar 57,32, siklus I 76,51 dan pada siklus II naik menjadi 81,92. Untuk siswa tuntas belajar (nilai ketuntasan 75) pada tes awal 30,81\%, tes siklus I 61,54\% setelah dilakukan refleksi terdapat 5 siswa yang tidak tuntas (nilai ulangan dibawah 75), namun secara keseluruhan sudah meningkat hasil belajarnya bila dilihat dari presentase ketuntasan siswa, dan pada tes siklus II semua siswa sudah mencapai ketuntasan 100\%.

Berdasarkan hasil penelitian mengenai penerapan model pembelajaran Contextual Teaching and Learning pada siswa kelas 2 MI Raden Rahmat, maka saran-saran yang diberikan sebagai sumbangan pemikiran untuk meningkatkan mutu pendidikan pada umumnya dan meningkatkan kompetensi peserta didik kelas 2 MI Raden Rahmat, sebagai berikut: 1) Bagi Sekolah Penelitian dengan penerapan model pembelajaran Contextual Teaching and Learning sangat membantu dalam meningkatkan mutu pembelajaran di sekolah, 2) Bagi Guru, bahwa untuk meningkatkan hasil belajar pendidikan aqidah akhlak diharapkan menggunakan penerapan model pembelajaran Contextual Teaching and Learning, demikian pula untuk meningkatkan keaktifan, kreativitas siswa dan keefektifan pembelajaran diharapkan menerapkan penerapan model pembelajaran Contextual Teaching and Learning, serta untuk memperoleh jawaban yang tepat, sesuai dengan tujuan penelitian disarankan untuk menggali pendapat atau tanggapan siswa.

\section{DAFTAR PUSTAKA}

Ani Anriani Sobandi, Asti Inayah. "Pengaruh Efektifitas Pembelarana Daring Terhadap Prestasi Siswa Pada Mapel Aqidah Akhlaq." THORIQOTUNA: JURNAL PENDIDIKAN ISLAM 4, no. 2 (2021): 301-19. https://doi.org/https://doi.org/10.47971/tjpi.v4i2.359.

Fahmi. "Strategi Pembelajaran Contextual Teaching and Learning Untuk Meningkatkan Keterampilan Berpikir Tingkat Tinggi." Prosiding Seminar Nasional Pendidikan IPA 2016, no. September 2016 (2016): 121-28.

Ibnu Rawandhy N. Hula. "Peningkatan Kompetensi Kaidah Bahasa Arab Bagi Pemula Menggunakan Al-Tadribat Al-Lughawiyah." Al-Ta'rib 8, no. 2 (2020): 213-28. https://doi.org/https://doi.org/10.23971/altarib.v8i2.2054 PENINGKATAN.

Mustaqim, Arif, and Ibnu Rawandhy N Hula. "INCREASING LEARNING OUTCOMES THROUGH.” Joumal:Education and Language Research Center(ELRC) 1, no. 1 (2021): 1-10. https://doi.org/https://doi.org/10.31219/osf.io/vgebx.

Qomaria Abusama, Kasim Yahiji, Damhuri, Ibnu Rawandy N. Hula. "Actuating Pendidikan Dalam Pandangan Al- Qur'an Dan Hadits.” Jurnal Al-Himayah 3, no. 3 (2020): 298-310. https://journal.iaingorontalo.ac.id/index.php/ah/article/view/2125.

Rasid Harahap, Zunaidi M. "Prospek Pembelajaran Aqidah Akhlak Menggunakan Model Contextual Teaching Learning Di Sekolah Dasar." EDUSOSHUM: Journal of Islamic Education and Social Humanities 1, no. 1 (2021): 45-54. https://doi.org/10.52366/edusoshum.v1i1.8.

Rizti, T M, and E Prihatnani. "Efektivitas Model Pembelajaran 3CM (Cool-Critical-CreativeMeaningfull) Terhadap Kemampuan Berpikir Kritis Siswa SMP.” Mosharafa: Jurnal ... 10 (2021):213-24.

https://journal.institutpendidikan.ac.id/index.php/mosharafa/article/view/945.

Ruto, Rikardus, Anselmus Mema, Maria Purnama Nduru, and Maria Kristina Ota. "Contextual Teaching and Learning Approach in Social Science: Its Role to Encourage Pupils' 
Cognitive Learning Achievement." Journal of Research in Instructional 1, no. 1 (2021): 43-52. https://doi.org/10.30862/jri.v1i1.11.

Saraswati, Shinta Almayra, Priyantini Widiyaningrum, Dyah Rini Indriyanti, and Universitas

Negeri Semarang. "Journal of Innovative Science Education Development of Mobile

Learning ( My Repro ) Based on Contextual Teaching Learning to Improve Cognitive

Understanding Senior High School Student." Journal of Innovation Science Education, no. 37

(2021): 37-48. https://doi.org/10.15294/JISE.V10I1.47824.

Surur, Misbakhus, and Muhamad Khoirur Roziqin. "Islamic Education Learning Process in

Evaluation Curriculum: The Minister of Religion Decree No . 183 and 184 of 2019” 1, no. 1 (2021): 2-6.

Susilowati, Evi. "Penggunaan 'Contexual Teaching and Learning' Dalam Pembelajaran Menulis Teks Puisi." Dinamika 2, no. 1 (2019): 19. https://doi.org/10.35194/jd.v2i1.676.

Tamam Syaifuddin, Luthfiyah Nurlaela, and Sukma Perdana P. "Contextual Teaching and Learning (CTL) Model to Students Improve Learning Outcome at Senior High School of Model Terpadu Bojonegoro." IJORER : International Journal of Recent Educational Research 2, no. 5 (2021): 528-35. https://doi.org/10.46245/ijorer.v2i5.143.

Tamur, Maximus, Valeria S Kurnila, Emilianus Jehadus, Sabina Ndiung, Jerito Pareira, and Syaharuddin Syaharuddin. "Learning from the Past: Meta-Analysis of Contextual Teaching-Learning of the Past Decade." International Journal of Education \& Curriculum Application $\quad 4, \quad$ no. 1 (2021): $1-10$. https://doi.org/https://doi.org/10.31764/ijeca.v4i1.3981.

Ayudia, Ayudia, Edi Suryanto, and Budhi Waluyo. (2017). Analisis Kesalahan Penggunaan Bahasa Indonesia Dalam Laporan Hasil Observasi Pada Siswa Smp. Basastra.

Suardi, Moh. (2021). Belajar \& Pembelajaran. Google : Google Buku.

Fiteriani, Ida, and Iswatun Solekha. (2016). Peningkatan Hasil Belajar Ipa Melalui Model Pembelajaran Contextual Teaching and Learning (Ctl) Pada Siswa Kelas V Mi Raden Intan Wonodadi Kecamatan Gadingrejo Kabupaten Pringsewn Tabun Pelajaran 2015/2016. Terampil: Jurnal Pendidikan Dan Pembelajaran Dasar

Hasibuan, M. Idrus. (2014). Model Pembelajaran Ctl (Contextual Teaching and Learning). Logaritma : Jurnal Ilmu-Ilmu Pendidikan Dan Sains

Kistian, Agus. (2108). Pengarub Model Pembelajaran Contextual Teaching and Learning (Ctl) Terbadap Hasil Belajar Matematika Siswa Kelas IV SD Negeri Langung Kabupaten Aceh Barat. Bina Gogik: Jurnal Ilmiah Pendidikan Guru Sekolah Dasar

Mustofa, Ali, and Ragil Saifulloh. (2017). Tafsir Surat Ar-Rabman Ayat 14 : Karakteristik Guru. Qolamuna: Jurnal Studi Islam

Nurrita, Teni. (2018). Pengembangan Media Pembelajaran Untuk Meningkatkan Hasil Belajar Siswa. Misykat: Jurnal Ilmu-Ilmu Al-Quran, Hadist, Syari'ah Dan Tarbiyah

Pebriana, Putri Hana. (2017). Peningkatan Keterampilan Menulis Puisi Bebas Dengan Menggunakan Pendekatan Kontekstual Siswa Sekolah Dasar. Publikasi Pendidikan

Penerapan Model Pembelajaran Kooperatif Tipe Examples Non Examples Dengan Menggunakan Alat Peraga Untuk. Meningkatkan Hasil Belajar Siswa Di Kelas VIII SMP N 1 Argamakmur.

UNIB : Scholar Repository [accessed 12 October 2021]

Penerapan Model Pemebelajaran Kontekstual (CTL, Contextual Teaching and Learning) Pada Sekolah Dasar. https://karyatulisku.com/penerapan-model-pemebelajaran 22/ [accessed 17 October 2021]

Pengaruh Strategi Pembelajaran Dan Minat Belajar Terhadap Hasil Belajar Matematika. Judika (Jurnal Pendidikan Unsika). https://journal.unsika.ac.id/index.php/judika/article/view/199 [accessed 10 October 2021]

Relevansi Prinsip-Prinsip Belajar Menurut Syaikh Az-Zarnuji Dalam Kitab Ta'lim Al-Muta'allim Dengan Prinsip-Prinsip Belajar Modern. Walisongo Repository http://eprints.walisongo.ac.id/id/eprint/12496/ [accessed 10 October 2021] 
Rijali, Ahmad. (2019). Analisis Data Kualitatif. Alhadharah: Jurnal Ilmu Dakwah

Susiloningsih, Wahyu. 2016. Model Pembelajaran CTL (Contextual Teaching and Learning) Dalam Meningkatkan Hasil Belajar Mahasiswa PGSD Pada MataKuliah Konsep IPS Dasar. Pedagogia : Jurnal Pendidikan

Aqib, Zainal., \& Chotibudin, M. Teori Dan Aplikasi Penelitian Tindakan Kelas: (PTK). Google Buku. https://books.google.co.id/books [accessed 12 October 2021]

Edi, Fandi Rosi Sarwo. Teori Wawancara Psikodignostik. Google Buku' https://books.google.co.id/books [accessed 12 October 2021]

Turrohmah, Maidah. 2017. Hubungan Kompetensi Profesional Guru Qur'an Hadist Dan Motivasi Belajar Terbadap Hasil Belajar Siswa Di Ma Nurul Ulum Tulungagung Kec Gading Rejo Kab Pringsewu. Karya Ilmiah UIN Malang 